\title{
ABSTRAK \\ PENGARUH REBUSAN BUAH MAHKOTA DEWA (PHALERIA \\ MACROCARPA) TERHADAP PENURUNAN TEKANAN \\ DARAH PADA LANSIA PENDERITA HIPERTENSI \\ DI DESA SENDANA KECAMATAN MAMBI \\ KABUPATEN MAMASA
}

\author{
Andan Firmansyah ${ }^{1,}$ Masyitah Wahab ${ }^{2,}$ Supratman $^{3}$, Abdullah $^{4}$ \\ (xi + 80 halaman + 7 Tabel + 7 lampiran $)$
}

Latar belakang :Hipertensi adalah tekanan darah persisten dimana tekanan sistoliknya diatas $140 \mathrm{mmHg}$ dan diastolik diatas $90 \mathrm{mmHg}$. Buah mahkota dewa (Phaleria macrocarpa) merupakan salah satu tanaman asli yang berasal dari Indonesia yang akhir-akhir ini popular sebagai tanaman yang dapat menyembuhkan berbagai macam penyakit.tanaman mahkota dewa dapat meningkatkan sistem kekebalan tubuh, mengurangi kadar gula darah, serta mengurangi penggumpalan darah. Kandungan flavonoid pada Buah mahkota dewa dapat digunakan sebagai antihipertensi sedangkan polifenol berfungsi sebagai antihistamin.

Tujuan penelitian ini adalah untuk membuktikan pengaruh rebusan buah mahkota dewa (Phaleria macrocarpa) Terhadap Penurunan Tekanan Darah Pada Lansia Di Desa Sendana Kecamatan Mambi Kabupaten Mamasa.

Metode : Desain penelitian ini yaitu quasi eksperimen, dengan rancangan penelitian two group, Pre testand Post test designmenggunakan kelompok control (pembanding) Dengan maksud untuk menguji bagaimana pengaruh rebusan buah mahkota dewa terhadap penurunan tekanan darah pada lansia. Sampel dalam penelitian ini berjumlah 20respondendengan penentuan sampel menggunakan Consecutive Sampling.dimana seluruh responden merupakan penderita hipertensi yang sedang tidak mengkonsumsi obat antihipetensi.

Hasil penelitian ini menunjukkan bahwaada pengaruh yang signifikan terhadap perubahan tekanan darah sebelum dan sesudah pemberian rebusan buah mahkota dewa $p$-value $0,004<0,005$ ( Ho ditolak dan Ha diterima).

Kata Kunci :hipertensi, buah mahkota dewa

Kepustakaan : 12 buku dari tahun 2007-2017 


\title{
ABSTRACT \\ THE INFLUENCE OF GODDESS MAHKOTA FRUIT (PHALERIA MACROCARPA) ON PRESSURE REDUCTION BLOOD IN ELDERLY PATIENTS OF HYPERTENSION IN SENDANA VILLAGE KECAMATAN MAMBI MAMASA REGENCY
}

\author{
Andan Firmansyah ${ }^{1,}$ Masyitah Wahab ${ }^{2,}$ Supratman $^{3}$, Abdullah $^{4}$ \\ $(\mathbf{x i}+80$ pages +7 Tables +7 attachments $)$
}

Background: Hypertension is persistent blood pressure where systolic pressure is above $140 \mathrm{mmHg}$ and diastolic is above $90 \mathrm{mmHg}$. The crown of the god fruit (Phaleria macrocarpa) is one of the original plants that originated from Indonesia which lately is popular as a plant that can cure various diseases. crown gods can enhance the immune system, reduce blood sugar levels, and reduce blood clots. Flavonoid content in the fruit of the god crown can be used as antihypertensive while polyphenols function as antihistamines.

The purpose of this study was to prove the effect of crown god (Phaleria macrocarpa) fruit decoction on Decreasing Blood Pressure in the Elderly in Sendana Village, Mambi District, Mamasa Regency.

Method: The design of this study is quasi-experimental, with a two-group study design, Pre-test and Post-test design using a control group (comparison) with a view to examining how the influence of the god's fruit decoction on blood pressure reduction in the elderly. The sample in this study amounted to 20 respondents with the determination of samples using Consecutive Sampling. where all respondents were hypertensive patients who were not taking antihypertensive drugs.

The results of this study indicate that there is a significant effect on changes in blood pressure before and after giving the fruit of the crown god p-value 0,004 $<0,005$ (Ho is rejected and $\mathrm{Ha}$ is accepted).

Keywords: hypertension, fruit of the crown of the god

Literature: 12 booksfrom2007-2017 


\section{PENDAHULUAN}

\section{Latar Belakang}

Menurut Tambayong (2000) yang dikutip oleh (Ismanto et al., 2014), hipertensi adalah peningkatan tekanan sistol dan diastol, yang tingginya tergantung umur individu yang terkena. Hipertensi adalah salah satu penyakit yang mengakibatkan angka kesakitan yang tinggi. Hipertensi sering kali disebut sebagai pembunuh gelap (silent killer) karena termasuk yang mematikan tanpa disertai dengan gejala lebih dahulu sebagai peringatan bagi korbannya. ( Joint National Committee 7,2011).

Hipertensi merupakan salah satu penyakit degeneratif yang prevalensinya dari tahun ke tahun mengalami peningkatan. Berdasarkan data World Health Organization (WHO) ada satu miliar orang di dunia menderita hipertensi dan dua per-tiga diantaranya berada di negara berkembang dan diprediksi pada tahun 2025 ada sebanyak 29\% orang dewasa di seluruh dunia menderita hipertensi (WHO, 2011) yang dikutip oleh(Astuti, 2016).

Pada tahun 2013, 25,8\% penduduk Indonesia menderita hipertensi, prevalensi kejadian hipertensi pada lansia usia 55-64 tahun sebanyak 45,9\%,

usia 65-74 tahun sbanyak $57,6 \%$, dan pada usia $>75$ tahun sebanyak 63,8\% (Kemenkes, 2014)

Sampai saat ini, hipertensi masih merupakan tantangan besar di Indonesia.Betapa tidak, hipertensi merupakan kondisi yang sering ditemukan pada pelayanan kesehatan primer kesehatan. Hal itu merupakan masalah kesehatan dengan prevalensi yang tinggi, yaitu sebesar 25,8\% (Riskesdas 2013).

Terdapat perbedaan tentang batasan hipertensi seperti diajukan oleh Kaplan (1990:205) yaitu pria, usia kurang dari 45 tahun, dikatakan hipertensi bila tekanan darah waktu berbaring diatas atau sama dengan 130/90 $\mathrm{mmHg}$, sedangkan pada usia lebih dari 45 tahun, dikatakan hipertensi bila tekanan darah diatas 145/95 mmHg. Sedangkan pada wanita tekanan darah diatas sama dengan 160/90 mmHg (Sharif La Ode, 2012).

Berdasarkan data proyeksi penduduk, diperkirakan tahun 
2017 terdapat 23,66 juta jiwa penduduk lansia di Indonesia $(9,03 \%)$. Diprediksi jumlah penduduk lansia tahun 2020 (27,08 juta), tahun $2025(33,69$ juta), tahun 2030 (40,95 juta) dan tahun 2035 (48,19 juta). Suatu negara dikatakan berstruktur tua jika mempunyai populasi lansia di atas tujuh persen (Soeweno). Gambar di bawah memperlihatkan persentase lansia di Indonesia tahun 2017 telah mencapai $\quad 9,03 \%$ dari keseluruhan penduduk. Selain itu, terlihat pula bahwa persentase penduduk 0-4 tahun lebih rendah dibanding persentase penduduk 5-9 tahun. Sementara persentase penduduk produktif 10-44 tahun terbesar jika dibandingkan kelompok umur lainnya(pusat data dan informasi,2017).

Tingginya resiko lansia terkena penyakit hipertensi di sebabkan oleh perubahanperubahan yang terjadi selama penambahan usia atau yang di sebut proses penuaan. Proses penuaan dapat menyebabkan perubahan dalam struktur dan fungsi tubuh. Salah satu proses penuaan yang menyebabkan meningkatnya resiko hipertensi ialah penuaan pada sistem kardiovaskuler (Donlon cit Stanley, 2007). Kondisi ini meyakinkan teori yang mengatakan semakin tua kemampuan tubuh pun semakin berkurang sehingga di perlukan penanganan lanjut terhadap penyakit hipertensi pada lansia (Ahmad, 2011).

Laporan dari Bidang Pelayanan Kesehatan, Dinas Kesehatan Kabupaten Mamasa tahun 2016. menunjukkan bahwa jumlah kesakitan 110.595 penderita. Adapun penyakit dengan jumlah penderita terbanyak dari urutan sepuluh besar penyakit adalah penyakit tekanan darah tinggi diurutan ke 4 dengan jumlah penderita 6.802 sedangkan yang di urutan pertama ada Infeksi Akut Lain pada Saluran pernafasan sebesar 29.261 penderita (Dinkes Mamasa, 2016).

Berdasarkan data dari Puskesmas Mambi Kab.Mamasa hipertensi selalu menduduki 5 besar penyakit terbanyak yang ditemukan dan lebih banyak ditemukan pada lansia.hipertensi merupakan penyakit dengan jumlah penderita terbanyak ke dua setelah penyakit ispa. Berdasarkan hasil study pendahuluan yang telah 
dilakukan oleh peneliti di Puskesmas mambi terdapat jumlah lansia pada tahun 2016 adalah 486 orang $\geq 60$ tahun, dan 337 orang $\geq 70$ tahun sampai tahun 2017(puskesmas mambi 2016).

\section{Pada survey awal yang} dilakukan oleh peneliti di wilayah penelitian mengenai pemanfaatan buah mahkota dewa, sebagian masyarakat mengatakan buah mahkota dewa digunakan sebagai obat herbal untuk menurunkan tekanan darah tinggi, terdapat banyak tanaman buah mahkota dewa didesa tersebut namun kurang di manfaatkan oleh masyarakat. Dari 10 orang yang diwawancarai, 8 orang mengatakan kurang memanfaatkan buah mahkota dewa sebagai obat penurun hipertensi dikarenakan mereka tidak mengetahui mengenai manfaat dari buah mahkota dewa dan lebih memilih pengobatan dari puskesmas, alasannya karena lebih cepat dan mudah. Tindakan pengobatan dapat dilakukan dengan 2 cara, seperti pengobatan tekanan darah tinggi yaitu farmakologis dan nonfarmakologis. Pengobatan nonfarmakologis sendiri dilakukan dengan mengontrol hipertensi, seperti pengaturan pola makan dan gaya hidup (Dalimartha, 2008). Sedangkan pengobatan secara farmakologis dilakukan dengan pemberian obat diuretik atau vasodilator (Brunner \& Suddarth, 2002).

Pengobatan alternative menjadi pilihan untuk mengatasi hipertensi, salah satunya dengan terapi herbal dengan manfaat yang tidak kalah dengan obat kimia bahkan dengan keuntungan tidak memiliki efek samping bagi penderita (Nurrahmani, 2012).

Buah mahkota dewa (Phaleria macrocarpa) merupakan salah satu tanaman asli yang berasal dari Indonesia yang akhir-akhir ini popular sebagai tanaman yang dapat menyembuhkan berbagai macam penyakit. Tanaman ini memiliki 1,5-2,5 meter, daunnya tunggal berbentuk lonjong, dan berujung lancip. Buahnya bulat dan berwarna merah tua jika matang. Tanaman ini berasal dai wilayah timur Indonesia yaitu Irian dan tumbuh subur pada ketinggian 10-1200 meter di atas permukaan laut (Azwar Agoes, 2010).

$\begin{array}{rrr}\text { Kandungan } & \text { Tanaman } \\ \text { mahkota dewa } & \text { mengandung }\end{array}$


senyawa saponin,flavonoid, dan saponin.Saponin sebagai fitonutrien, yang sering disebut juga deterjen alam, bersifat antibakteri dan antivirus. Selain itu, tanaman mahkota dewa dapat meningkatkan sistem kekebalan tubuh, mengurangi kadar gula darah, serta mengurangi penggumpalan darah. Kandungan flavonoid pada Buah mahkota dewa dapat digunakan sebagai antihipertensi sedangkan polifenol berfungsi sebagai antihistamin (Pranata, 2014),

Menurut Albinur (2011), senyawa yang terkandung di dalam buah mahkota dewa adalah senyawa flavonoid yaitu senyawa yang terdiri dari 15 atom karbon yang umumnya tersebar di dunia tumbuhan, lebih dari 2000 flavonoid yang berasal dari tumbuhan telah di identifikasi. Hasil penelitian

\section{METODOLOGI PENELITIAN}

\section{Desain penelitian}

Desain penelitian adalah macam atau jenis penelitian tertentu yang terpilih untuk di laksanakan dalam rangka mencapai tujuan penelitian yang telah ditetapkan. Desain penelitian
Sudewa (2014) tersebut diketahui bahwa terdapat penurunan tekanan darah sistolik dan diastolik pada kelompok intervensi setelah diberikan buah mahkota dewa.Mengkonsumsi buah mahkota dewa, secara rutin satu kali sehari selama tujuh hari dapat menurunkan tekanan darah tinggi pada penderita hipertensi. Hal ini membuktikan bahwa buah mahkota dewa (Phaleria macrocarpa) efektif untuk menurunkan tekanan darah tinggi(ragil 2011).

Berdasarkan uraian latar belakang di atas, maka pertanyaan penelitian yang di ajukan "apakah terdapat pengaruh rebusan buah mahkota dewa (Phaleria macrocarpa) Terhadap Penurunan Tekanan Darah Pada Lansia"?

merupakan bentuk rancangan yang digunakan dalam melakukan prosedur penelitian (Hidayati, 2007).

Jenis penelitian ini adalah
quasi eksperimen, dengan
rancangan penelitian two group,
Pre test and Post test design.
Dengan maksud untuk menguji
bagaimana pengaruh rebusan buah


mahkota dewa terhadap penurunan

tekanan darah pada lansia.

Desain penelitian yaitu:

Tabel 3.3. Rancangan Penelitian

01

$\mathbf{X}$

$\mathbf{O 2}$

Rebusan Buah Mahkota

Pre-test

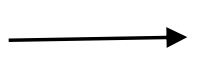

Dewa

Post-test

Keterangan :

$\mathrm{O} 1$ = pre-test

$=\mathrm{X}=$ intervensi / perlakuan

$\mathrm{O} 2=$ post-test

\section{HASIL PENELITIAN DAN PEMBAHASAN}

\section{Hasil Penelitian}

\section{Analisis Univariat}

Distribusi responden berdasarkan Tekanan Darah Sistolik/Diastolik Sebelum dan sesudah Intervensi Pada Kelompok Eksperimen dan kontrol

Tabel 4.2 Tekanan Darah Sistolik/Diastolik Sebelum dan sesudah Intervensi Pada Kelompok Eksperimen dan kontrol

\begin{tabular}{c|c|c|c|c}
\hline \multirow{2}{*}{ Variabel } & \multicolumn{4}{|c}{ Kelompok } \\
\cline { 2 - 5 } & Eksperimen & \multicolumn{2}{|c}{ Kontrol } \\
\cline { 2 - 5 } & $\mathbf{N}$ & $\%$ & $\mathbf{N}$ & $\%$ \\
\hline Tekanan Darah Sistolik & & & & \\
Sebelum Intervensi & & & & \\
$140 \mathrm{mmHg}$ & 1 & $10 \%$ & 3 & $30 \%$ \\
$150 \mathrm{mmHg}$ & 7 & $70 \%$ & 2 & $20 \%$ \\
$160 \mathrm{mmHg}$ & 1 & $10 \%$ & 3 & $30 \%$ \\
$170 \mathrm{mmHg}$ & - & - & 1 & $10 \%$ \\
$180 \mathrm{mmHg}$ & 1 & $10 \%$ & 1 & $10 \%$ \\
\hline Tekanan Darah Sistolik & & & & \\
Sesudah Intervensi & & & & \\
\hline
\end{tabular}




\begin{tabular}{c|c|c|c|c}
\hline $120 \mathrm{mmHg}$ & 10 & 100 & & \\
$140 \mathrm{mmHg}$ & - & $\%$ & - & - \\
$150 \mathrm{mmHg}$ & - & - & 4 & $40 \%$ \\
& & - & 6 & $60 \%$ \\
\hline Tekanan Darah Diastolik & & & & \\
Sebelum Intervensi & & & & \\
80 & - & - & 2 & $20 \%$ \\
90 & 6 & $60 \%$ & 7 & $70 \%$ \\
100 & 4 & $40 \%$ & 1 & $10 \%$ \\
\hline Tekanan Darah Diastolik & & & & \\
Sesudah Intervensi & & 100 & & 100 \\
80 & 10 & $\%$ & 10 & $\%$ \\
\hline
\end{tabular}

Sumber: data tahun 2018

Dari Tabel diatas, diketahui bahwa TD sistolik responden sebelum intervensi pada kelompok eksperimen memiliki TD sistolik 140 sebanyak 1 responden (10\%), TD sistolik 150 sebanyak 7 responden $(70 \%)$, TD sistolik 160 sebanyak 1 responden (10\%), TD sistolik 180 sebanyak 1 responden (10\%). dari Tabel diatas, diketahui bahwa TD diastolik responden sebelum intervensi pada kelompok eksperimen memiliki TD diastolik 90 sebanyak 6 responden (60\%), TD diastolik 100 sebanyak 4 responden (40\%).

Dari Tabel 4.2 diatas, diketahui bahwa TD sistolik responden setelah intervensi pada kelompok eksperimen memiliki TD sistolik 120 sebanyak 10 responden $(100 \%)$. sedangkan TD diastolik responden setelah intervensi pada kelompok eksperimen memiliki TD diastolik 80 sebanyak 10 responden (100\%).
Dari Tabel 4.2 diatas, diketahui bahwa TD sistolik responden sebelum kontrol pada kelompok kontrol memiliki TD sistolik 140 sebanyak 3 responden (30\%), TD sistolik 150 sebanyak 2 responden (20\%), TD sistolik 160 sebanyak 3 responden (30\%), TD sistolik 170 sebanyak 1 responden (10\%), TD sistolik 180 sebanyak 1 responden (10\%) sedangkan TD diastolik responden sebelum kontrol pada kelompok kontrol memiliki TD diastolik 80 sebanyak 2 responden (20\%), TD diastolik 90 sebanyak 7 responden (70\%), TD diastolik 100 sebanyak 1 responden (10\%)

Dari Tabel diatas, diketahui bahwa TD sistolik responden setelah kontrol pada kelompok kontrol memiliki TD sistolik 140 sebanyak 4 responden (40\%), TD sistolik 150 sebanyak 6 responden (60\%) sedangkan TD diastolik responden setelah kontrol pada kelompok kontrol 
memiliki TD diastolik 80 sebanyak 10

responden (100\%).

Distribusi Tekanan Darah Sistolik/Diastolik Sebelum Dan Sesudah intervensi pada kelompok eksperimen dan kontrol

Tabel 4.3Tekanan Darah Sistolik/Diastolik Sebelum dan sesudah Intervensi Pada Kelompok Eksperimen dan Kontrol

\begin{tabular}{llllll}
\hline No. & \multicolumn{1}{c}{$\begin{array}{c}\text { Variable/ } \\
\text { Kelompok }\end{array}$} & Min & Max & mean & \multicolumn{1}{c}{ SD } \\
\hline $\mathbf{1}$ & EKSPERIMEN & & & & \\
& Sistolik Sebelum & 140 & $\mathbf{1 8 0}$ & $\mathbf{1 5 3 . 0 0}$ & $\mathbf{1 0 . 5 9 3}$ \\
\cline { 2 - 6 } & Sistolik Sesudah & $\mathbf{1 2 0}$ & $\mathbf{1 2 0}$ & $\mathbf{1 2 0 . 0 0}$ & $\mathbf{. 0 0 0}$ \\
\cline { 2 - 6 } & Diastolik Sebelum & $\mathbf{9 0}$ & $\mathbf{1 0 0}$ & $\mathbf{9 4 . 0 0}$ & $\mathbf{5 . 1 6 4}$ \\
\cline { 2 - 6 } & Diastolik Sesudah & $\mathbf{8 0}$ & $\mathbf{8 0}$ & $\mathbf{8 0 . 0 0}$ & $\mathbf{. 0 0 0}$ \\
\hline \multirow{2}{*}{} & KONTROL & & & & \\
& Sistolik Sebelum & 140 & $\mathbf{1 8 0}$ & $\mathbf{1 5 5 . 0 0}$ & $\mathbf{1 3 . 5 4 0}$ \\
\cline { 2 - 6 } & Sistolik Sesudah & 140 & $\mathbf{1 5 0}$ & $\mathbf{1 4 6 . 0 0}$ & $\mathbf{5 . 1 6 4}$ \\
\cline { 2 - 6 } & Diastolik Sebelum & $\mathbf{8 0}$ & $\mathbf{1 0 0}$ & $\mathbf{8 9 . 0 0}$ & $\mathbf{5 . 6 7 6}$ \\
\cline { 2 - 6 } & Diastolik Sesudah & $\mathbf{8 0}$ & $\mathbf{8 0}$ & $\mathbf{8 0 . 0 0}$ & $\mathbf{. 0 0 0}$ \\
\hline
\end{tabular}

Sumber: data tahun 2018

Berdasarkan tabel di 4.3 atas, menunjukkan nilai rata-rata (mean) responden pada kelompok perlakuan sistolik sebelum intervensi adalah 153.00 (SD: 10.593) Sedangkan nilai rata-rata (mean) sistolik sesudah intervensi adalah 120.00 (SD: 0.000). dan nilai rata-rata (mean) diastolik sebelum intervensi adalah 94.00 (SD: 5.164) Sedangkan nilai rata-rata (mean) diadtolik sesudah intervensi adalah 80.00 (SD: .000) sementara nilai rata-rata (mean) responden pada kelompok kontrol sistolik sebelum adalah $\quad 155.00 \quad$ (SD: 13.540 ) Sedangkan nilai rata-rata (mean) sistolik sesudah adalah 146.00 (SD: 5.164). dan nilai rata-rata (mean) diastolik sebelum kontrol adalah 89.00 (SD: 5.676) Sedangkan nilai rata-rata (mean) diadtolik sesudah kontrol adalah 80.00 (SD: .000). 


\section{Analisis Bivariat}

\section{Hasil Uji Statistik Wilcoxon}

\section{Tabel 4.4 Hasil Uji Statistik Wilcoxon Kelompok Eksperimen Dan Kelompok Kontrol}

\begin{tabular}{|c|c|c|c|}
\hline No. & $\begin{array}{c}\text { Variable/ } \\
\text { Kelompok }\end{array}$ & $\begin{array}{c}\text { Median } \\
\text { Min/Max }\end{array}$ & $\mathbf{P}$ \\
\hline \multirow[t]{5}{*}{1} & EKSPERIMEN & & \multirow{3}{*}{0,004} \\
\hline & Sistolik Sebelum & $150,00(140 / 180)$ & \\
\hline & Sistolik Sesudah & $120,00(120 / 120)$ & \\
\hline & Diastolik Sebelum & $90,00(90 / 100)$ & \multirow{2}{*}{0,004} \\
\hline & Diastolik Sesudah & $80,00(80 / 80)$ & \\
\hline \multirow[t]{5}{*}{2} & KONTROL & & \\
\hline & Sistolik Sebelum & $155,00(140 / 180)$ & \multirow{2}{*}{0,070} \\
\hline & Sistolik Sesudah & $150,00(140 / 150)$ & \\
\hline & Diastolik Sebelum & $80,00(80 / 100)$ & \multirow{2}{*}{0,007} \\
\hline & Diastolik Sesudah & $90,00(80 / / 80)$ & \\
\hline
\end{tabular}

Sumber: data tahun 2018

Berdasarkan tabel di atas, dapat diketahui bahwa dengan menggunakan uji willcoxon pada kelompok eksperimen di dapatkan hasil p-value untuk TD sistolik dan diastolik sama yaitu sebesar $\mathrm{p}=0,004$ (p $0,004<0,005)$. Sedangkan pada kelompok kontrol didapatkan hasil pvalue untuk TD darah sistolik sebesar $\mathrm{p}=0,070$ dan TD diastolik sebesar $\mathrm{p}=$ 0,007. Dari hasil tersebut $\mathrm{p}$-value pada tekanan darah sistolik lebih besar dari pada diastolik.

\section{PEMBAHASAN}

Berdasarkan hasil penelitian menunjukkan bahwa karakteristik
Dari hasil tersebut diatas menunjukkan bahwa pada kelompok eksperimen di dapat hasil ada pengaruh yang signifikan terhadap perubahan tekanan darah sebelum dan sesudah pemberian rebusan buah mahkota dewa $p$-value $0,004<0,005$ ( Ho ditolak dan Ha diterima) kemudian pada kelompok kontrol dengan hasil yg di dapatkan pada tabel diatas, dapat di simpulkan bahwa tidak ada pengaruh terhadap tekanan darah dengan hasil $p$-value $<a$ ( Ho di terima dan Ha ditolak).

Distribusi Responden Menurut Umur menunjukkan bahwa yang berumur 60 tahun sebanyak 3 orang (30\%), yang 
berumur 61 tahun sebanyak 2 orang (20\%), responden yang berumur 62 tahun sebanyak 1 orang (10\%), responden yang berumur 63 tahun sebanyak 1 orang (10\%), responden yang berumur 64 tahun sebanyak 1 orang $(10 \%)$, responden yang berumur 67 tahun sebanyak 1 orang (10\%), responden yang berumur 68 tahun sebanyak 1 orang (10\%). Sedangkan pada kelompok kontrol menunjukkan bahwa responden yang berumur 60 tahun sebanyak 2 orang (20\%), yang berumur (62 tahun) sebanyak 2 orang (20\%), responden yang berumur (63 tahun) sebanyak 3 orang $(30 \%)$, responden yang berumur (64 tahun) sebanyak 1 orang (10\%), responden yang berumur (66 tahun) sebanyak 1 orang $(10 \%)$, responden yang berumur (67 tahun) sebanyak 1 orang (10\%).

Hipertensi di kenal secara luas sebagai penyakit kardiovaslkuler. Di perkirakan telah menyebabkan $4.45 \%$ dari beban penyakit secara global,dan prevalensinya hamper sama besar di Negara berkembang maupun Negara maju. Hipertensi adalah suatu keadaan ketika seseorang mengalami peningkatan tekanan darah di atas normal yang mengakibatkan peningkatan angka kesakitan (morbiditas) dan angka kematian (mortilitas) (Sharif La Ode, 2012).

Pravelansia hipertensi meningkat sesuai umur, dan $40 \%$ penderits hipertensi berusia lebih dari 65 tahun. Laki-laki dan obesitas meningkat resiko hipertensi. Beberapa faktor yang terkait proses menua dapat meningkat resiko lansia mengalami hipertensi. Seperti contohnya kekakuan pada aorta, peningkatn afterload (membutuhkan daya yang lebih banyak untuk memompa darah dari ventrikel), dan peningkatan tahan vaskuler. Perubahan reflek baroreseptor di indikasikan dengan fluktuasi tekanan darah selama melakukan aktivitas fisik atau mengalakukan aktivitas fisik atau mngalami stress emosional (Sofia Rhosma Dewi, 2014).

Hipertensi juga didefinisikan sebagai tekanan darah sistolik $\geq 140$ mmHg dan atau tekanan darah diastolik $\geq 90 \mathrm{mmHg}$ yang terjadi pada 
seseorang klien pada tiga kejadian terpisah (Wajan Juni, 2010).

Buah dari mahkota dewa (Phaleria macrocarpa) adalah yang paling sering digunakan dalam pengobatan tradisional dengan mencampurkan dengan bahan-bahan lainnya. Kandungan flavonoid pada Buah mahkota dewa dapat digunakan sebagai antihipertensi. Selain itu, buah Phaleria macrocarpa juga dapat digunakan untuk mengobati berbagai macam penyakit seperti kanker, diabetes mellitus, alergi, hati, penyakit jantung, gagal ginjal, penyakit darah, hipertensi, stroke, berbagai penyakit kulit, gatal-gatal, nyeri dan flu.

Kandungan kimia dalam mahkota dewa yang berpengaruh terhadap tekanan darah adalah flavonoid. Flavonoid dapat menurunkan Systemic Vascular Resistance (SVR) karena menyebabkan vasodilatasi(Yulisa, 2016).

Pengobatan alternative menjadi pilihan untuk mengatasi hipertensi, salah satunya dengan terapi herbal dengan manfaat yang tidak kalah dengan obat kimia bahkan dengan keuntungan tidak memiliki efek samping bagi penderita (Nurrahmani, 2012).

Sudewa (2014) tersebut diketahui bahwa terdapat penurunan tekanan darah sistolik dan diastolik pada kelompok intervensi setelah diberikan buah mahkota dewa.Mengkonsumsi buah mahkota dewa, secara rutin satu kali sehari selama tujuh hari dapat menurunkan tekanan darah tinggi pada penderita hipertensi. Hal ini membuktikan bahwa buah mahkota dewa (Phaleria macrocarpa) efektif untuk menurunkan tekanan darah tinggi(ragil 2011).

Langkah-langkah pembuatan rebusan daging buah mahkota dewa dalam penelitian ini dengan cara ambil daging buah mahkota dewa berwarna merah yang sudah di keringkan di bawah teriknya matahari, kemudian ambil 15 gr daging buah mahkota dewa rebus dengan air sebanyak $300 \mathrm{ml}$ sampai tersisa $150 \mathrm{ml}$, Setelah dingin baru di minum.

Cara penggunaan rebusan buah mahkota dewa adalah dengan cara minumlah setiap pagi hari setelah 
bangun tidur, Setelah minum tidak boleh minum minuman yang mengandung kafein dan melakukan aktivitas berat, Lakukan setiap pagi selama 1 minggu, lalu hentikan dulu, sebab kalau dilakukan terus menerus, khawatir tekanan darah penderita turun terlalu rendah dan akan berbahaya kalau berubah jadi tekanan darah rendah .

Berdasarkan hasil penelitian kelompok eksperimen didapatkan sebelum intervensi dapat dilihat dari Tabel 4.2 diatas, diketahui bahwa TD sistolik responden sebelum intervensi pada kelompok eksperimen memilikiTD sistolik140 sebanyak 1 responden (10\%), TD sistolik 150 sebanyak 7 responden (70\%), TD sistolik 160 sebanyak 1 responden (10\%), TD sistolik 180 sebanyak 1 responden (10\%), sedangkan Dari Tabel 4.2 diatas, diketahui bahwa TD diastolik responden sebelum intervensi pada kelompok eksperimen memilikiTD diastolik90 sebanyak 6 responden (60\%), TD sistolik 100 sebanyak 4 responden (40\%). Dan setelah intervensi dapat di lihat Dari
Tabel 4.3diatas, diketahui bahwa TD sistolik responden setelahintervensi pada kelompok eksperimen memilikiTD sistolik120 sebanyak 10 responden (100\%), sedangkan Dari Tabel 4.5 diatas, diketahui bahwa TD diastolik responden setelahintervensi pada kelompok eksperimen memilikiTD diastolik80 sebanyak 10 responden (100\%).

Berdasarkanhasilpenelitian kelompok kontrol didapatkan sebelum intervensi dapat di lihat dari Tabel 4.2 diatas, diketahui bahwa TD sistolik responden sebelum kontrol pada kelompok kontrol memilikiTD sistolik140 sebanyak 3 responden (30\%), TD sistolik 150 sebanyak 2 responden (20\%), TD sistolik 160 sebanyak 3 responden (30\%), TD sistolik 170 sebanyak 1 responden (10\%), TD sistolik 180 sebanyak 1 responden (10\%), sedangkan TD diastolik responden sebelum kontrol pada kelompok kontrol memilikiTD diastolik80 sebanyak 2 responden (20\%), TD sistolik 90 sebanyak 7 responden (70\%), TD sistolik 100 sebanyak 1 responden (10\%), 
Berdasarkanhasilpenelitian kelompok kontrol didapatkan setelah intervensidapat di lihat dari Tabel 4.2 diatas, diketahui bahwa TD sistolik responden setelahkontrol pada kelompok kontrol memilikiTD sistolik140 sebanyak 4 responden (40\%), TD sistolik150 sebanyak 6 responden (60\%), sedangkan TD diastolik responden setelahkontrol pada kelompok kontrol memilikiTD diastolik80 sebanyak 10 responden (100\%).

Berdasarkan tabel di 4.3 atas, menunjukkan nilai rata-rata (mean) responden pada kelompok perlakuan sistolik sebelum intervensi adalah 153.00 (SD: 10.593) Sedangkan nilai rata-rata (mean) sistolik sesudah intervensi adalah 120.00 (SD: 0.000). dan nilai rata-rata (mean) diastolik sebelum intervensi adalah 94.00 (SD: 5.164) Sedangkan nilai rata-rata (mean) diadtolik sesudah intervensi adalah 80.00 (SD: .000) sementara nilai rata-rata (mean) responden pada kelompok kontrol sistolik sebelum adalah $\quad 155.00 \quad$ (SD: 13.540 ) Sedangkan nilai rata-rata (mean) sistolik sesudah adalah 146.00 (SD: 5.164). dan nilai rata-rata (mean) diastolik sebelum kontrol adalah 89.00 (SD: 5.676) Sedangkan nilai rata-rata (mean) diadtolik sesudah kontrol adalah 80.00 (SD: .000).

Hasil analisi tentang pengaruh sebelum diberikan dan sesudah diberikan rebusan buah mahkota dewa terhadap penurunan tekanan darah pada lansia Diatas dengan menggunakan uji wilcoxon, pada kelompok kontrol Berdasarkan Berdasarkan tabel 4.4 di atas, dapat diketahui bahwa dengan menggunakan uji willcoxon di dapatkan hasil pvalue untuk TD sistolik dan diastolik sama yaitu sebesar $\mathrm{p}=0,004(\mathrm{p}$ $0,004<0,005)$. Sedangkan pada kelompok kontrol didapatkan hasil pvalue untuk TD darah sistolik sebesar $\mathrm{p}=$ 0,070 dan TD diastolik sebesar $\mathrm{p}$ $=0,007$. Dari hasil tersebut $\mathrm{p}$-value pada tekanan darah sistolik lebih besar dari pada diastolik.

Dari hasil tersebut diatas menunjukkan bahwa pada kelompok eksperimen di dapat hasil ada pengaruh yang signifikan terhadap 
perubahan tekanan darah sebelum dan sesudah pemberian rebusan buah mahkota dewa $p$-value $0,004<0,005$ ( Ho ditolak dan Ha diterima) kemudian pada kelompok kontrol dengan hasil yg di dapatkan, di simpulkan bahwa tidak ada pengaruh terhadap tekanan darah dengan hasil $p$-value $<a$ ( Ho di terima dan Ha ditolak).

Sejalan dengan penelitian yang dilakukan oleh I Wayan Bagus Sudewa,Amatus YudiIsmantoSefti Rompas pada tahun 2014 tentang pengaruh buah mahkota dewa (Phaleria macrocarpa) terhadap KESIMPULAN DAN SARAN

\section{Kesimpulan}

Data yang diperoleh dari hasil penelitian mengenai pengaruh rebusan buah mahkota dewa yang dapat menurunkan tekanan darah pada lansia di Desa Sendana adalah sebagai berikut :

Dari hasil yang di dapatkan pada kelompok eksperimen sebelum intervensi, menunjukkan TD sistolik paling banyak pada TD sistolik 150 (70\%), sedangkan TD diastolik penurunan tekanan darah pada penderita hipertensi di desa werdhi agung kecamatan dumoga tengah kabupaten bolaang mongondow, Hasil penelitian ini menunjukkan adanya hubungan yang signifikan antara buah mahkota dewa (Phaleria macrocarpa) dengan penurunan tekanan darah pada penderita hipertensi $\mathrm{p}$-value $=0,000$

Dari hasil pembahasan di atas dapat dikatakan pemberian rebusan buah mahkota dewa sangat baik diberikan pada klien yang menderita hipertensi untuk menurunkan tekanan darahnya.

responden sebelum intervensi memiliki TD diastolik paling banyak pada TD diastolik 90 (60\%). Sementara TD responden sebelum pada kelompok kontrol TD sistolik terbanyak 140 dan 160 masing-masing (30\%) dan TD diastolik terbanyak pada TD diastolik 90 (70\%). Hasil tersebut menunjukkan bahwa lebih banyak responden yang hipertensi baik kelompok eksperimen maupun kelompok kontrol. 


\begin{tabular}{|c|c|}
\hline $\begin{array}{ll}\text { Dari } & \text { hasil yang di } \\
\text { dapatkan } & \text { sesudah pada }\end{array}$ & $\begin{array}{l}\text { kontrol didapatkan hasil p- } \\
\text { value untuk TD darah sistolik }\end{array}$ \\
\hline eksperimen, & sebesar $p=0,070$ dan \\
\hline menunjukkan TD sistolik & diastolik sebesar $\mathrm{p}=0,007$. \\
\hline paling banyak pada TD sistolik & Dari hasil tersebut p-value \\
\hline $120(100 \%)$, sedangkan TD & pada tekanan darah sistolik \\
\hline diastolik responden sesudah & lebih besar dari pada diastolik. \\
\hline intervensi memiliki TD & Dari hasil tersebut \\
\hline diastolik paling banyak pada & diatas menunjukkan bahwa \\
\hline TD diastolik $80 \quad(100 \%)$ & pada kelompok eksperimen di \\
\hline Sementara $\quad$ TD responden & dapat hasil ada pengaruh yang \\
\hline sesudah pada kelompok & signifikan terhadap perubahan \\
\hline kontrol TD sistolik terbanyak & tekanan darah sebelum dan \\
\hline $150(60 \%)$ dan TD diastolik & sesudah pemberian rebusan \\
\hline terbanyak pada TD diastolik & buah mahkota dewa p-value \\
\hline $80 \quad(100 \%)$. Hasil tersebut & $0,004<0,005$ ( Ho ditolak dan \\
\hline menunjukkan bahwa pada & Ha diterima) kemudian pada \\
\hline kelompok eksperimen TD & kelompok kontrol dengan hasil \\
\hline normal sedangkan kelompok & yg di dapatkan pada tabel \\
\hline kontrol tetap hipertensi & diatas, dapat \\
\hline Dari hasil yang di & bahwa tidak ada pengaruh \\
\hline dapatkan dapat diketahui & terhadap tekanan \\
\hline bahwa dengan $\mathrm{m}$ & dengan hasil $p$-value $<a$ ( Ho \\
\hline uji willcoxon pac & dan Ha ditolak). \\
\hline
\end{tabular}

eksperimen di dapatkan hasil p-value untuk TD sistolik dan diastolik sama yaitu sebesar $p$ $=0,004 \quad(\mathrm{p} \quad 0,004<0,005)$. Sedangkan pada kelompok

\section{Saran}

\section{Bagi Institusi Pendidikan}

Penelitian ini di harapkan dapat menambah kepustakaan bagi 


$$
\begin{array}{lr}
\text { pendidikan } & \text { dalam } \\
\text { menambah pengetahuan dan } & \text { mengenai } \\
\text { imformasi } & \text { hipertensi } \\
\text { penyakit } & \text { dalam } \\
\text { khususnya } & \text { pengobatan } \\
\text { menggunakan } & \text { cara } \\
\text { herbal dengan } & \text { rebusan buah } \\
\text { memberikan } & \text { rebang } \\
\text { mahkota dewa yang dapat } & \\
\text { menurunkan tekanan darah } \\
\text { pada lansia. }
\end{array}
$$

\section{Bagi Masyarakat}

Penelitian ini

diharapkan dapat meberikan informasi kepada masyarakat tentang pentingnya pengetahuan mengenai penyakit hipertensi, khususnya bagi lansia.

\section{Bagi Pembaca}

Peneliti

mengharapkan penelitian ini dapat dikembangkan lagi terutama terkait masalah menurunkan tekanan darah tinggi pada penderita hipertensi dalam rangka meningkatkan kesehatan dan kmencegah terjadinya hipertensi yang lebih berat.

\section{DAFTAR PUSTAKA}

Astuti, A. (2016). Tiga faktor penggunaan obat herbal hipertensi, 1(June), 81-87.

Depkes. (2007). Pharmaceutical care. Pharmaceutical Care Untuk Penyakit Hipertensi, 150.

Ismanto, A. Y., Rompas, S., Studi, P., Keperawatan, I., Kedokteran, F., Sam, U., \& Manado, R. (2014). Pengaruh buah mahkota dewa(Phaleria macrocarpa) terhadap penurunan tekanan darah pada penderita hipertensi.

Julianti, E. D., Nurjanah, N., \& Seotrisno, U. S. S. (2007). Bebas Hipertensi dengan Terapi Jus. Jakarta.

Kemenkes.RI. (2014). Pusdatin Hipertensi. Infodatin, 
(Hipertensi), 1-7.

https://doi.org/10.1177/109019

817400200403

Kusuma Hardi, \& Nurarif Huda Armin. (2015). Aplikasi Asuhan Keperawatan Berdasarkan Diagnosa Medis dan Nanda Nic-Noc. (Yudha, Ed.) (Ed, 2). Jogjakarta: Penerbit Mediaction.

Machfoedz, I. (2017). Metodologi Penelitian. Yogyakarta: Fitramaya.

Muhith Abdul. (2016). Pendidikan Keperawatan Gerontik. (Andi, Ed.) (Ed. 1). Yogyakarta.

Nuraini, B. (2015). Risk factors of hypertension, 4, 10-19.

Pamungkas, rian adi. (2017). metodologi riset keperawatan. (T.ismail, Ed.) (pertama). jakarta: trans info media (TM).

Pranata, T. (2014). Tanaman toga (buah mahkota dewa) (aksara suk). sleman.
Robert E. Kowalski. (2010). Terapi hipertensi. (Astuti Rahmani, Ed.) (Ed.1). Bandung: Qanita.

Saryono (2011). Metodologi Penelitian Kesehatan. (A. Setiawan, Ed.). Yogyakarta: Mitra Cendekia.

Sharif La Ode. (2012). Asuhan Keperawatan Gerontik. (N. ArTeam, Ed.) (Ed. 1). Yogyakarta.

Soenarta, A. A., Erwinanto, Mumpuni, A. S. S., Barack, R., Lukito, A. A., Hersunarti, N., ... Pratikto, R. S. (2015). Pedoman tatalaksana hipertensi pada penyakit kardiovaskular. Pedoman Tatalaksana Hipertensi Pada Penyakit Kardiovaskuler, 1, 1-2.

Sofia Rhosma Dewi. (2014). Buku Ajar Keperawatan Gerontik. (H. Rahmadhani, Ed.) (Ed.1). Yogyakarta: Deepublish. 
Swarjana, I. K. (2015).

Jakarta.

METODOLOGI PENELITIAN

KESEHATAN. (Andi, Ed.) (Ed,

II). Yogyakarta.

Yulisa, R. (2016). Aplikasi

pemberian rebusan daging buah mahkota dewa terhadap

Wajan Juni, U. (2010). penurunan tekanan darah pada Keperawatan Kardiovaskular. ny $X$ dengan hipertensi (Carolina Sally, Ed.) (Ed. 3). dipuskesmas gajahan surakarta. 